metodychni rekomendatsii do vyvchennia spetskursu dlia studentiv spetsialnosti 013 «Pochatkova osvita» osvitnoho stupenia mahistr. Mukachevo: MDU [in Ukrainian].

Honcharenko, N. A. (2007). Rozvytok polikulturnoi kompetentnosti pedahohiv zahalnoosvitnikh navchalnykh zakladiv [Development of multicultural competence of teachers of general educational institutions]: navchalnyi posibnyk. Kherson: RIPO [in Ukrainian].

Dzhurinskij A. N. (2002). Polikul'turnoe vospitanie: sushchnost' i perspektivy razvitiya [Polycultural education: the nature and development prospects]. Pedagogika (Vol. 10, p. 93-96). [in Russian].

Kondratieva O.M. (2017). Formuvannia polikulturnoi kompetentnosti maibutnikh uchyteliv pochatkovoi shkoly (na zasadakh linhvokrainoznavchoho pidkhodu) [Formation of multicultural competence of future teachers of elementary school (on the basis of the linguistic-ethnographic approach)] dys. kand. ped. nauk: 13.00.04. Kyiv [in Ukrainian].

\title{
ATROSHCHENKO T.
}

Mukachevo State University, Ukraine

\section{REALIZATION OF THE MULTICULTURAL COMPONENT IN PROFESSIONAL PREPARATION OF FUTURE TEACHERS OF PRIMARY SCHOOL}

The article has substantiated the ways of implementing a multicultural component in the training of future primary school teachers. We have consider polycultural component as one of the components of vocational and pedagogical training of future teachers of primary school. Its content is realized in its field of activity, aimed at the development of professional skills and values, value-orientation basis of personality and promotes formation of readiness of the future specialist for multicultural interaction.

The composition of the multicultural component of vocational and pedagogical training includes a set of interrelated elements as external (ethno-cultural, socio-cultural, intercultural), and internal (ideological) plans that determine the content of vocational and pedagogical training of students on the basis of introduction theoretical and practical material characterized by multicultural orientation into the educational process. In accordance with such understanding of the multicultural component of vocational and pedagogical training, we can distinguish following main structural elements: ethnocultural; socio-cultural intercultural. The academic discipline «Theory and practice of formation of interethnic tolerance of future teachers of primary school» has been presented and its importance in multicultural preparation of masters students of specialty 013 «Primary education». It has been recommended innovative methods and forms of educational work that contribute to the preparation of a multicultural specialist in the elementary educational establishment. The author of the article has pointed the importance of pedagogical practice in multicultural training for future teachers of primary forms, independent and professionally directed extra-curricular work, students' research activity in the perspective of multicultural issues.

Key words: teacher of primary school, dialogue of cultures, culture of interethnic communication, interethnic tolerance, multicultural component, multicultural education, professional training, value orientations

Стаття надійшла до редакції 04.09.2018 p.

УДК 377.36:63-027.561

\section{ВІТАЛІЙ БАРБІНОВ}

Полтавський центр професійно-технічної освіти

\section{СТРУКТУРА ГОТОВНОСТІ МАЙБУТНІХ КВАЛІФІКОВАНИХ РОБІТНИКІВ АГРАРНОЇ ГАЛУЗІ ДО ПРОФЕСІЙНОЇ ДІЯЛЬНОСТІ}

у статті на основі аналізу наукових праць визначено поняття готовності майбутніх кваліфікованих робітників аграрної галузі до професійної діяльності. Готовність майбутніх кваліфікованих робітників аграрної галузі до професійної діяльності розглядається як складне утворення, що визначається єдністю та взаємообумовленістю таких структурних компонентів: мотиваційного, пізнавального, практичного, суб'єктного. Доведено, що результатом готовності майбутніх кваліфікованих робітників аграрної галузі до професійної діяльності $є$ здатність випускників професійно-технічних навчальних закладів успішно виконувати професійні обов'язки на ринку праці.

Ключові слова: готовність до професійної діяльності, кваліфіковані робітники аграрної галузі, професійно-технічний навчальний заклад, професійі знання, уміння, навички

Характерною ознакою сучасного розвитку аграрної галузі України є динамічне техніко-технологічне оновлення виробничих процесів, що грунтуються на знаннях, інноваціях, інтелектуальному і професійному потенціалах. Відтак, зростає потреба у фахівцях аграрної галузі зі сформованим професійним мисленням та 
здатністю до розв'язання складних професійних завдань. Відповідно, актуалізується пошук інноваційних методик формування готовності майбутніх кваліфікованих робітників аграрної галузі до професійної діяльності, що стає основним фактором їхньої успішної діяльності в умовах наукоємного та високотехнологічного агропромислового виробництва.

Аналіз науково-педагогічної літератури дає підстави до висновку, що проблема професійної підготовки учнів та студентів в аграрних закладах освіти була і $є$ предметом спеціальних досліджень. Педагогічні дослідження 3 професійної підготовки майбутніх фахівців аграрної галузі здебільшого присвячені таким питанням: формування професійного інтересу учнів ПТНЗ аграрного профілю (Л. Романенко); підготовки майбутніх фахівців аграрної галузі до управлінської діяльності (В. Свистун); тенденцій розвитку та впровадження дистанційного навчання фахівців аграрної галузі в країнах Європейського Союзу(ЄС) (Г. Гірник); наукових основ наступності в системі безперервної професійної аграрної освіти (П. Олійник); організації самостійної роботи студентів агроінженерних спеціальностей (І.Бендера); нових підходів до вищої аграрної освіти (Д. Мельничук); дидактичних основ ресурсноорієнтованого навчання дисциплін комп'ютерного циклу студентів аграрних коледжів (Н. Кононец); адаптації аграрних навчальних закладів до підготовки спеціалістів сільського господарства у ринкових умовах; методів і форм організації навчання у вищій аграрній школі(П. Лузан) тощо.

Водночас, у науково-педагогічній літературі бракує досліджень, зорієнтованих на формування готовності майбутніх кваліфікованих робітників аграрної галузі до професійної діяльності.

Мета статті - визначити структуру готовності майбутніх кваліфікованих робітників аграрної галузі до професійної діяльності

Аналіз наукових праць І. Гавриш (2006), І. Коваль (2017), В. Кулько (2011) уможливив визначити поняття «готовність до професійної діяльності» як: 1) інтегральну освіту, тобто ЗУН, спеціально-професійні знання, індивідуальні нахили і комплекс психологічних особливостей, які забезпечують високу ефективність фахового функціонування особистості; 2) складне, особистісне утворення, яке включає мотиви, що спрямовують майбутніх фахівців на усвідомлення необхідності вирішення завдань, і $\epsilon$ результатом підготовки у навчальних закладах; 3) активний стан особистості, що визначає успішне вирішення завдання.

Н. Ничкало (2001) доводить, що сучасна професійна підготовка майбутніх кваліфікованих робітників виступає засобом опанування сучасної картини світу, розвитку національної свідомості майбутнього фахівця; створення умов для набуття освіти, яка дозволяє швидко адаптуватися у соціумі; професіоналізації як набуття професійної компетентності майбутнього фахівця, оволодіння фундаментальними, прикладними знаннями, високою культурою організації та реалізації професійної діяльності; самореалізації як набуття умінь продуктивної життєдіяльності, професійної діяльності та самовдосконалення.

На думку К. Дурай-Новакової, терміносполучення «готовність до діяльності» можна тлумачити як цілісне вираження усіх підструктур особистості, зорієнтованих на продуктивне виконання професійних функцій. Готовність до професійної діяльності розглядається нею як складне структурне утворення, яке базується на позитивних установках, мотивах, набутому досвіді використання знань і навичок на практиці, та передбачає засвоєння цінностей професійної діяльності (Дурай-Новакова, 1983).

Нам імпонує думка А. Зуєвої (2018), яка у своїх наукових пошуках дійшла висновку, що «готовність майбутніх техніків-механіків до професійної діяльності» доцільно розглядати як інтегральну якість особистості майбутнього спеціаліста агропромислового комплексу, що включає оптимальну суму теоретичних знань, практичних умінь, навичок та психологічну установку на досягнення мети майбутньої професійної діяльності.

У нашому дослідженні готовність майбутніх кваліфікованих робітників аграрної галузі до професійної діяльності розглядається як цілісне внутрішнє особистісне утворення, що характеризується їх здатністю до самостійного отримання необхідних ЗУН, індивідуального та групового виконання пізнавальних, технологічних, конструкторських та інших завдань, які завершуються наданням механізаторських послуг. Готовність майбутніх кваліфікованих робітників аграрної галузі до професійної діяльності розглядаємо як складне утворення, що визначається єдністю та взаємообумовленістю таких структурних компонентів: мотиваційного, пізнавального, практичного, суб'єктного (рис. 1.).

Як бачимо з рисунку 1, мотиваційний компонент - це професійно значущі потреби, інтереси та мотиви професійної діяльності майбутніх кваліфікованих робітників аграрної галузі (грошовий заробіток, бажання просування кар'єрними сходинками у професійній діяльності, можливість продовження навчання, бажання уникнути критики з боку керівництва, колег, бажання уникнути можливих покарань та негараздів, потреба в досягненні соціального престижу та повага з боку оточуючих, задоволення від процесу роботи та результатів діяльності, можливість найбільш повної самореалізації саме у цій професійній діяльності), що детермінують прагнення особистості до успішного вирішення професійних завдань та позитивне ставлення до обраної професії.

Пізнавальний компонент - розуміння соціальної значущості, необхідності обраної професії, знання шляхів досягнення мети, прагнення до самостійного здобування ЗУН, спеціально-професійних знань, побудови знань як процесу, який складається з трьох етапів: «Розвідка»(етап пошуку професійно важливої для майбутніх кваліфікованих робітників аграрної галузі інформації), «Інтерпретація» (етап обробки, аналізу, інтерпретації знайденої інформації та її адаптація до конкретних навчальних та професійних цілей і завдань), 
«Створення нових ідей»(етап узагальнення та систематизації інформації, прийняття рішень, генерації нових ідей).

Практичний компонент - наявність у майбутніх кваліфікованих робітників аграрної галузі сформованих на належному рівні професійних ЗУН, що відповідають кваліфікаційним вимогам обраної професії, які відображені в освітньо-кваліфікаційній характеристиці випускника ПТНЗ;спеціальнопрофесійних ЗУН, які додатково сприятимуть успішній діяльності випускника в аграрній галузі; мобілізація й актуалізація професійних ЗУН, адаптація до професійних вимог та умов діяльності; володіння засобами розв'язання професійних завдань (пізнавальних, технологічних, конструкторських тощо); здатність застосовувати набуті ЗУН для практичного вирішення професійних завдань в аграрній галузі.

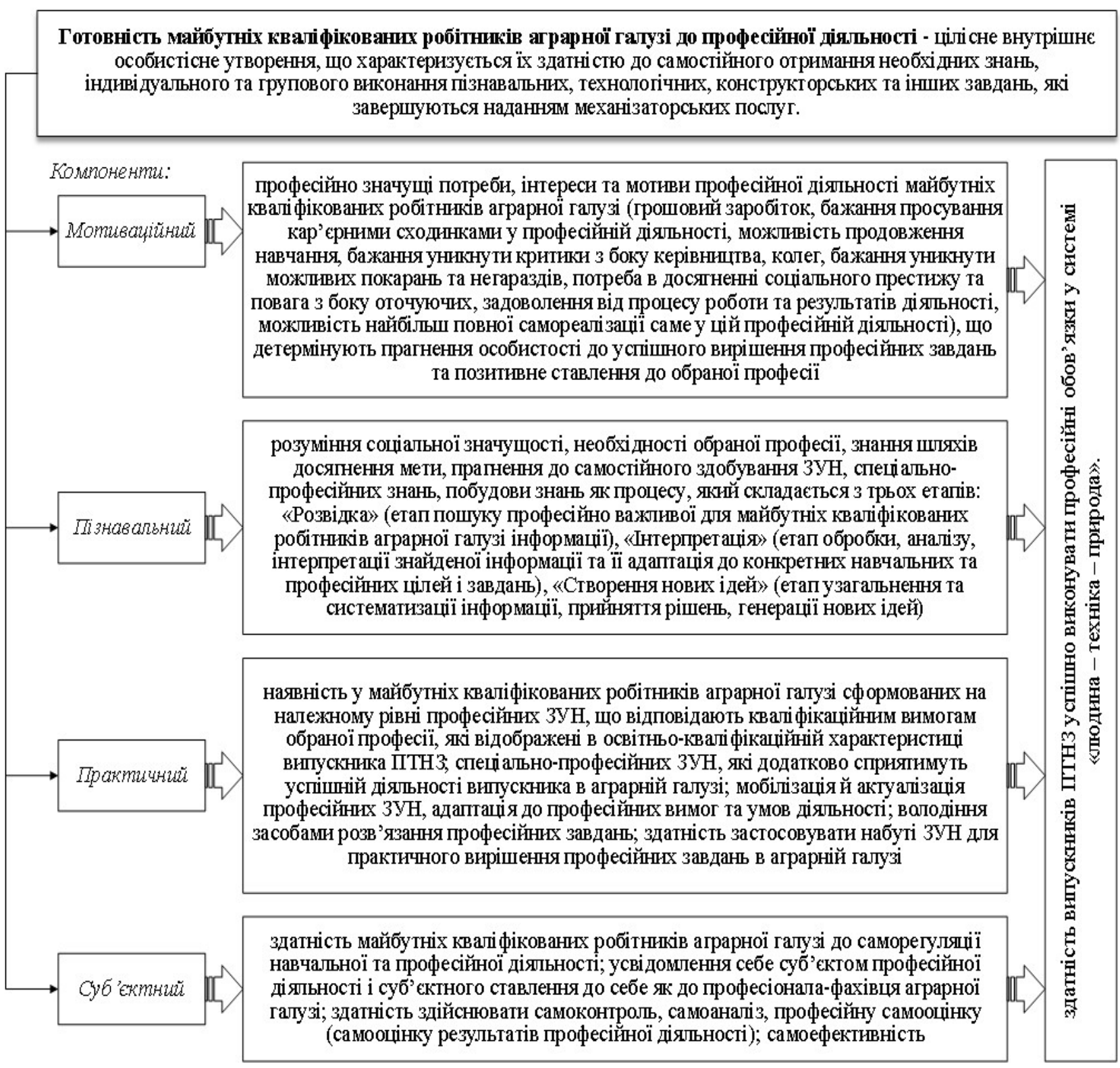

Рис. 1. Структура готовності майбутніх кваліфікованих робітників аграрної галузі до професійної діяльності

Суб'єктний компонент - здатність майбутніх кваліфікованих робітників аграрної галузі до саморегуляції навчальної та професійної діяльності; усвідомлення себе суб'єктом професійної діяльності і суб'єктного ставлення до себе як до професіонала-фахівця аграрної галузі; здатність здійснювати самоконтроль, самоаналіз, професійну самооцінку (самооцінку результатів професійної діяльності); самоефективність. У контексті дослідження, саморегуляція навчальної та професійної діяльності трактується як уміння майбутніх кваліфікованих робітників аграрної галузі бачити кінцеву мету діяльності, самостійно знаходити шляхи її досягнення і домагатися здійснення. Як слушно зазначає М. Гриньова, 
результатом саморегуляції є формування у майбутнього кваліфікованого робітника цілеспрямованості, організованості, уміння володіти собою в будь-якій ситуації (Гриньова, 2008). Самоконтроль розглядаємо як здатність майбутнього кваліфікованого робітника аграрної галузі цілеспрямовано стежити за собою, контролювати свої вчинки, усвідомлювати свою поведінку і діяльність, постійно звіряючи їх із заданою програмою та поставленою метою.

Професійну самооцінку визначаємо як прояв професійної самосвідомості особистості майбутнього кваліфікованого робітника аграрної галузі: усвідомлення норм, правил професійної діяльності,формування професійного кредо; співвіднесення себе з певним професійним еталоном; оцінка себе іншими, фахівцямипрофесіоналами; самооцінка, в якій виокремлюються 1)когнітивний аспект, тобто усвідомлення своєї діяльності, та 2) емоційний аспект, що виявляється через систему ставлень до процесу та результатів праці.

Слід особливо відзначити, що з позицій ергономіки трудова діяльність розглядається як процес перетворення інформації й енергії, що відбувається в системі «людина - знаряддя праці - предмет праці навколишнє середовище» (Давідіч, Куш, Понкратов, 2011). 3 цієї ж позиції професійна діяльність майбутніх кваліфікованих робітників аграрної галузі відбувається у системі «людина - техніка - природа». Варто наголосити, що ця система, на відміну від інших, суто технічних систем, характеризується рядом особливостей, які визначають властивості, що притаманні професійній діяльності майбутніх кваліфікованих робітників аграрної галузі:

Універсальність. Кожна конкретна техніка призначена для виконання обмеженої кількості заздалегідь відомих завдань в аграрній галузі. Загалом, кваліфікований робітник аграрної галузі може виконувати безліч різних завдань різними способами у залежності від власних здібностей та отриманих ЗУН, а також 3 урахуванням природно-кліматичних умов. Універсальність системи проявляється в тім, що кваліфікований робітник може, використовуючи по-новому ті або інші властивості системи, застосовувати ії для рішення інших завдань, які не планувалися при проектуванні системи і не передбачалися інструкцією.

Адаптивність. Адаптивність системи «людина - техніка - природа» полягає в значно більшому діапазоні їі пристосованості до умов іï функціонування, що постійно змінюються (науково-технічний прогрес в аграрній галузі, використання технологічних інновацій у сільськогосподарському виробництві, вдосконалення сільськогосподарської техніки, врахування природно-кліматичних умов, екологія, проблеми навколишнього природного середовища тощо). Тож професійна діяльність майбутніх кваліфікованих робітників аграрної галузі передбачає гнучку адаптацію до умов функціонування системи.

Мінливість. Зміна стану кваліфікованого робітника аграрної галузіпід впливом різних факторівзумовлює як позитивні, так і негативні сторони системи «людина - техніка природа».Позитивною доцільно вважати можливість широкого пристосування до темпових,інтенсивних та екстенсивних вимог роботи в аграрній галузі. Негативним єзалежність якості професійної діяльності від факторів, здатних погіршувати її стан -стомлюваність, хвороба, природні катаклізмитощо (Давідіч, Куш, Понкратов, 2011).

Адекватність. Сукупність властивостей, що характеризують пристосованість системи «людина техніка - природа» до виконання поставленого завдання. Адекватність визначається: інформаційною організацією системи «людина - техніка - природа» (наявність у структурі системи необхідних інформаційних технологій, програм обробки інформації, каналів зв'язку, навченого відповідним чином персоналу тощо); фізичними характеристиками (механічними, енергетичними, природнимитощо); засобами активації функціонування (нова сільськогосподарська техніка, новітні технології у сільськогосподарському виробництві, комп'ютеризація аграрної галузі, раціональність використання природних ресурсів тощо).

Суб'єктність техніки. Для нинішнього етапу розвитку технічної реальності, зокрема, в аграрній галузі, характерно формування специфічної «суб'єктності техніки». Так звана «суб’єктність техніки» розглядається науковцями як властивість техніки, покликана доповнити власну суб'єктність кваліфікованого робітника шляхом передачі технічним пристроям деяких інтелектуальних функцій людини.

Функціонування аграрної галузі. Тісна взаємодія людини 3 природою і технікою. Висока різноманітність природно-кліматичних умов, земельних ресурсів. Сезонність аграрного виробництва, відтак, неповна зайнятість робітників упродовж року та нестабільність заробітної платні.

Багатогалузевий характер. Зменшення зайнятості у сільському господарстві. Необхідність освоєння аграрними підприємствами ринкової поведінки та тимчасового пристосування до недосконалого механізму господарювання перехідного періоду. Необхідність надання різноманітних послуг, пов'язаних із запровадженням новітніх технологій, матеріально-технічним постачанням та інформаційноконсультативним супроводом. Створення умов для розвитку приватних господарств, підприємництва, агробізнесу як основи інноваційного розвитку аграрної галузі (Герасимова, 2015).

Таким чином, готовність майбутніх кваліфікованих робітників аграрної галузі до професійної діяльності можна трактувати як здатність випускників ПТНЗ успішно виконувати професійні обов'язки у системі «людина - техніка - природа». Вона є показником успішності майбутніх кваліфікованих робітників аграрної галузі в роботі та різновидом установки до можливості виконувати свої професійні обов'язки у цій системі.

У контексті дослідження процесу формування готовності майбутніх кваліфікованих робітників аграрної галузі до професійної діяльності як педагогічної проблеми вважаємо за необхідне здійснити аналіз 
стану професійної підготовки майбутніх кваліфікованих робітників аграрної галузі в Україні та за кордоном.

\section{Список використаних джерел}

Гавриш, І. В. (2006). Теоретико-методологічні основи формування готовності майбутніх учителів до інноваиійної професійної діяльності. (Дис. д-ра пед. наук). Харків.

Герасимова, І. Г. (2015). Формування професійної мобільності майбутніх фахівиів аграрної сфери: монографія. Вінниця: ПП «ТД «Едельвейс і К».

Гриньова, М. В. (2008). Саморегулячія : навч.-метод. посіб. Полтава : АСМІ.

Давідіч, Ю. О., Куш, С.І., Понкратов, Д. П. (2011).Ергономічне забезпечення транспортних процесів: навч. посібник.Х. : ХНАМГ. 392 с.

Дурай-Новакова, К. М. (1983). Формирование профессиональной готовности студентов к педагогической деятельности (Автореф. дис. д-ра пед. наук). Москва.

Зуєва, А.Б. (2018). Педагогічні умови формування професійного мислення майбутніх техніків-механіків у вищих аграрних навчальних закладах I-II рівнів акредитаиії. (Дис. канд. пед. наук). Київ.

Коваль, І. С. (2017). Формування професійної готовності майбутніх рятувальників до діяльності в екстремальних умовах. (Дис. канд. пед. наук). Львів.

Кулько, В.А. (2011). Сутність і структура готовності майбутніх аграріїв до професійної діяльності. Вісник Запорізького наиіонального університету, 2 (15), 193-197.

Ничкало, Н. Г. (2001). Неперервна професійна освіта як філософська та педагогічна категорія. Неперервна професійна освіта: теорія і практика (с. 9-22). Вип. 1.

\section{References}

Havrysh, I. V. (2006). Teoretyko-metodolohichni osnovy formuvannia hotovnosti maibutnikh uchyteliv do innovatsiinoi profesiinoi diialnosti. (Dys. d-ra ped. nauk). Kharkiv.

Herasymova, I. H. (2015). Formuvannia profesiinoi mobilnosti maibutnikh fakhivtsiv ahrarnoi sfery: monohrafiia. Vinnytsia: PP «TD «Edelveis i K».

Hrynova, M. V. (2008). Samorehuliatsiia : navch.-metod. posib. Poltava : ASMI.

Davidich, Yu. O., Kush, Ye. I., Ponkratov, D. P. (2011). Erhonomichne zabezpechennia transportnykh protsesiv: navch. posibnyk.Kh. : KhNAMH.

Durai-Novakova, K. M. (1983). Formyrovanye professyonalnoi hotovnosty studentov $k$ pedahohycheskoi deiatelnosty (Avtoref. dys. d-ra ped. nauk). Moskva

Zuieva, A.B. (2018). Pedahohichni umovy formuvannia profesiinoho myslennia maibutnikh tekhnikiv-mekhanikiv u vyshchykh ahrarnykh navchalnykh zakladakh I-II rivniv akredytatsii. (Dys. kand. ped. nauk).

Koval, I. S. (2017). Formuvannia profesiinoi hotovnosti maibutnikh riatuvalnykiv do diialnosti v ekstremalnykh umovakh. (Dys. kand. ped. nauk). Lviv.

Kulko, V.A. (2011). Sutnist i struktura hotovnosti maibutnikh ahrariiv do profesiinoi diialnosti. Visnyk Zaporizkoho natsionalnoho universytetu, 2 (15), 193-197.

Nychkalo, N. H. (2001). Neperervna profesiina osvita yak filosofska ta pedahohichna katehoriia. Neperervna profesiina osvita: teoriia i praktyka (s. 9-22). Vyp. 1.

\section{BARBINOV V.}

SEI "Poltava Center for Vocational Education", Ukraine

\section{STRUCTURE OF READINESS OF FUTURE SKILLED WORKERS OF AGRARIAN SECTOR FOR PROFESSIONAL ACTIVITY}

In the article, on the basis of the analysis of scientific papers, the concept of the willingness of future skilled workers of the agrarian branch to professional activity is defined. The readiness of the future skilled workers of the agrarian branch to professional activity is viewed as a complex formation, determined by the unity and interdependence of such structural components: motivational, cognitive, practical, subjective. It is proved that the result of readiness of the future skilled workers of the agrarian branch to professional activity is the ability of graduates of vocational schools to successfully perform professional duties in the labor market.

The readiness of future skilled workers of the agrarian sector to professional activity is interpreted as the ability to perform professional duties in the system "man - technology - nature". It is an indicator of the success of future skilled workers in the agrarian sector in the work and the type of installation to the ability to carry out their professional duties in this system. In the context of the study of the process of forming the readiness of future skilled workers of the agrarian sector for professional activity as a pedagogical problem, the analysis of the state of professional training of future skilled workers of the agrarian sector in Ukraine and abroad is substantiated.

Key words: readiness for professional activity, skilled workers of agrarian branch, vocational and technical educational institution, knowledge and skills, skills

Стаття надійшла до редакції 02.07. 2018 р. 